\title{
THE SYNOVIAL MEMBRANE SOME OBSERVATIONS IN NORMAL AND ARTHRITIC HUMAN JOINTS
}

BY

\author{
K. MAUNSELL, FRED WRIGLEY, T. C. HIGHTON, and L. B. HOLT \\ From the MacLean Laboratory, Hospital of St. John and St. Elizabeth, \\ the Department of Rheumatic Diseases, West London Hospital, and the \\ Wright Fleming Institute of Microbiology, St. Mary's Hospital, London.
}

Little is known concerning the behaviour of the normal human synovia owing to the difficulty of obtaining normal synovial fluid for study. In particular, it is not known whether or not the human joint, normal or diseased, allows natural antibodies or acquired immune antibodies to pass into the synovial fluid. Such information is clearly of importance in arriving at a correct understanding of such pathological processes as rheumatoid arthritis and inflammatory arthritis of other origin, and we have therefore investigated normal and pathological synovial fluids for the presence of natural anti-A and anti-B antibodies, and for acquired immune antibodies such as those developed after diphtheria immunization. To complete the study, we decided to test synovial effusions also for those blood group specific substances known to be secreted in other mucinous secretions of ectodermal and endodermal origin.

This research could not have been completed without the generous co-operation of three normal subjects who voluntarily allowed us to conduct experiments upon them, including the withdrawal of synovial fluid, and to these volunteers we wish to express our great indebtedness.

Our investigations and results are presented in three sections:

(1) Investigation of synovial fluids from normal human knee joints

(a) for the presence of natural antibodies

(b) for the presence of acquired immune antibodies.

(2) Investigation of synovial effusions from arthritic human knee joints

(a) for the presence of natural antibodies

(b) for the presence of acquired immune antibodies.

(3) Investigation of synovial effusions from arthritic human knee joints for the presence of blood-gioup specific substances.

The knee joint was selected because of its easy accessibility and because one can be certain of inserting a needle into its cavity. The technique used was to raise an intradermal wheal with 2 per cent. procaine solution on the medial aspect of the joint. The site selected was opposite the midline of the patella and so placed that when a needle was driven in a lateral direction and horizontally, it lay under the femoral surface of the patella. By using this technique it is obvious that once the needle is under the patella it is in the knee joint. 
We made the error at first of being too considerate, and attempting to infiltrate the capsule with local anaesthetic so that the volunteer would feel no pain, but since this procedure caused contamination of the synovial fluid with procaine, we subsequently ceased using infiltration with local anaesthetic. This meant that the subject experienced a sharp pain on penetration of the joint capsule, but this was only of short duration. It was found that by the use of this technique it was possible to obtain up to $0.5 \mathrm{ml}$. synovial fluid from each knee joint of the volunteers.

It has been stated that the normal knee joint contains only this amount of fluid. In each case we were fortunate enough to be able to draw off this amount, which allowed us to conduct the experiments on the presence of iso-agglutinin antibodies, but was not sufficient to obtain information about the presence of blood-group specific substances in the normal human synovial fluid.

Two natural antibodies, anti-A and anti-B iso-agglutinins, circulate in the human plasma. Anti-A agglutinins are present in the sera of persons of group B, and anti-B agglutinins in subjects of group A; both occur in individuals of group $\mathrm{O}$, but neither is present in subjects of group AB. If plasma or serum containing iso-agglutinins is mixed with red cells characterized by the opposing agglutinogens A or B, agglutination of the red cells occurs. Neither anti-A serum nor anti-B serum agglutinates $\mathrm{O}$ cells as they lack the $\mathrm{A}$ and $\mathrm{B}$ agglutinogens. The potency of the agglutinating sera can be measured by titration. As the technique of agglutination is simple and the reactions are clear cut, it was hoped that the investigation of the normal human synovial fluid for the presence of natural blood-group antibodies would be a useful first step in our examination of the behaviour of the synovial membrane and the nature of the synovial fluid.

It is now known that the group specific substances $A$ and $B$ which determine the person's blood group also occur in a closely related form in the cells of almost all the organs of the body. They occur in two forms, water-soluble and alcoholsoluble. The latter is confined to the tissues, but the former is secreted into the tissue fluids by certain individuals. The water-soluble group specific substances have been found in mucinous secretions, e.g. saliva, gastric juice, hydrocele fluid, and the fluid of ovarian mucinous and pseudo-mucinous cysts. However, in only 80 per cent. of all individuals are these agglutinogens found in the secretions. These people are called "secretors" whereas those who do not secrete the substances are called "non-secretors". The saliva of secretors contains the bloodgroup factor in a high concentration. It is, therefore, possible to test for these substances serologically.

When saliva of a secretor is mixed with a serum containing the opposing anti-A antibodies, the group substances are capable of combining with them and thus inhibit their agglutinating property. The strength of this " inhibition" can be measured by titration. It seemed of interest to determine whether or not the group specific substances would be present in the synovial effusions as well as in other mucinous fluids.

Synovial fluid and saliva were chosen as mucinous material for these investigations and the inhibition index of the saliva and of the corresponding synovial fluid 
was compared. The sera were also examined to obtain evidence as to whether or not passage of blood group substances from the serum into the synovial cavity occurred.

\section{Investigation of Synovial Fluids from Normal Human Knee Joints}

\section{Presence of Natural Antibodies}

Normal Volunteers.

(1) Miss M., medical student, aged 21. Group O. No history of fibrositis or arthritis.

(2) Mrs. Cr., aged 43. Group B. Slight " fibrositis " in the past. On clinical examination both knee joints were normal. $X$ ray of the knee joints showed no abnormal changes.

(3) Mr. P., aged 26. Group O. Slight muscular pains in both thighs. On clinical examination both knee joints were normal. $X$ ray of the knee joints showed no abnormal changes.

Synovial Fluid.-The fluids were stored at $4^{\circ} \mathrm{C}$., without preservative, and examined 8 to 10 days later. The materials were highly viscous yellow liquids which adhered to the walls of the glass tubes at room temperature. At $37^{\circ} \mathrm{C}$. they were less viscous and could be pipetted off. They contained some granular precipitates; the fluid of the first of the volunteers was less viscous than the others.

Blood.-On the day that th:ir knee joints were punctured, 8 to $10 \mathrm{ml}$. blood was collected from the volunteers. The bloods were stored for 24 hours at $4^{\circ} \mathrm{C}$. The sera were then taken off under sterile conditions and stored at $4^{\circ} \mathrm{C}$. without preservative; these samples were also examined 8 to 10 days later. Standard red cells were taken on the day of the examination and the suspensions were made up in 3 per cent. sodium citrate. The suspension contained about 2 per cent. packed cells.

Technique of Titration for Iso-Agglutinins.-The technique of titration for antibodies was essentially the same as that described by Taylor and Ikin (1939). Serial dilutions of serum and of corresponding synovial fluid were made up in normal saline with a graduated Pasteur pipette, and an equal volume of the appropriate blood cells was added to each of the serial dilutions (about $0.04 \mathrm{ml}$.), e.g. B cells to fluids of a person of Group A. The titrations were set up in duplicate and were allowed to stand for 2 hours in the incubator at $37^{\circ} \mathrm{C}$. The suspensions were shaken up before reading. The reading was done macroscopically and microscopically. As controls, the serial dilutions were tested against group $\mathrm{O}$ cells.

TABLE I

EXAMINATION OF NORMAL SYNOVIAL FLUID AND BLOOD-SERA FOR ANTI-A AND ANTI-B ISO-AGGLUTININS

\begin{tabular}{|c|c|c|c|c|c|}
\hline \multirow{3}{*}{$\begin{array}{l}\text { Normal } \\
\text { Volunteers }\end{array}$} & \multirow{3}{*}{$\begin{array}{l}\text { Blood } \\
\text { Group }\end{array}$} & \multicolumn{4}{|c|}{ Titre of Iso-Agglutinins } \\
\hline & & \multicolumn{2}{|c|}{ Anti-A } & \multicolumn{2}{|c|}{ Anti-B } \\
\hline & & Serum & $\begin{array}{c}\text { Synovial } \\
\text { Fluid }\end{array}$ & Serum & $\begin{array}{l}\text { Synovial } \\
\text { Fluid }\end{array}$ \\
\hline Miss $\mathbf{M}$. & $\mathbf{O}$ & 512 & Nil & 256 & Nil \\
\hline Mrs. Cr. .. & B & 512 & Nil & - & - \\
\hline Mr. P. .. & $\mathbf{O}$ & 128 & Nil & 128 & Nil \\
\hline
\end{tabular}


The examination of undiluted synovial fluid was hindered by a false agglutination of cells of all groups, which was assumed to be due to the high viscosity of the material. This phenomenon was less noticeable and the clumping was easily broken up when the viscosity was lowered by dilution of the material and by warming the fluid to $37^{\circ} \mathrm{C}$. For this reason the synovial fluid was examined only from dilutions 1 in 4 onwards, and at $37^{\circ} \mathrm{C}$. Attempts to lower the viscosity by adding hyaluronidase were abandoned as the latter caused inhibition of the agglutination.

Results.-The serum of Case 1 (group O) had an anti-A titre of 512 and an anti-B titre of 256, that of Case 2 (group B) an anti-A titre of 512, and that of Case 3 (group O) an anti-A titre of 128 and an anti-B titre of 128 . In the synovial fluids of the three cases no iso-antibodies were detected (normally less than 1 in 4 ), although it must be admitted that traces of antibodies may have been present in the undiluted fluid. In spite of this the results are in striking contrast to the usual high titres in the corresponding sera. The normal synovial membrane thus acts as a barrier to the passage of iso-antibodies and allows none, or only traces, to enter the synovial cavity.

Presence of Acquired Immune Antibodies.-Since evidence was obtained that the normal blood agglutinins did not enter the normal synovial cavity to any significant degree, it was decided to determine whether antibodies due to an acquired immunity entered the normal knee joint. Therefore, a volunteer had some synovial fluid aspirated after being given a dose of diphtheria P.T.A.P.

Mr. P., aged 26 years, was given $0.2 \mathrm{ml}$. P.T.A.P. intramuscularly with some general and local reaction resulting. Four weeks later the serum titre was more than 200 units per ml., whereas the titre in the synovial fluid from the knee joint was only 15 units per ml., giving a ratio of synovial fluid to sera titre of under $7 \cdot 5$ per cent.

The normal synovial membrane thus acted as a barrier to the passage of the diphtheria immune antibodies.

\section{Investigation of Synovial Effusions from Arthritic Human Knee Joints}

It seemed of interest to determine whether or not a diseased synovial membrane continues to act as a barrier to natural and acquired immune antibodies.

\section{Presence of Natural Antibodies}

Material.-All synovial effusions were tapped under sterile conditions and the fluids stored at $4^{\circ} \mathrm{C}$. without preservative. After 8 to 10 days the precipitate had settled, or (as in a few cases) a mucinous globule had formed which was firm enough to allow the withdrawal of a clear sample by a Pasteur pipette. This sample was centrifuged to clear any remaining debris and the resulting supernatant fluid was used for the agglutination test. The blood samples were examined as described above. In Table II the 33 cases examined are tabulated.

The phenomenon of "false agglutination" described for the synovial fluid also occurred when synovial effusions were examined. Undiluted samples were, therefore, excluded from these investigations and the reading of the results started with a dilution of 1 in 2 saline.

Results.-The effusions of patients of group B agglutinated group A cells; the effusions of patients of group A agglutinated group B cells; and the effusions of individuals of group $O$ agglutinated both $A$ and $B$ cells. $O$ cells were not agglutinated. A comparison of the titres of the antibodies in the synovial effusions and in the corresponding sera showed almost equal values (see Table II). 
Thus it is apparent that synovial effusions whether resulting from rheumatoid arthritis or other arthritic conditions contain the natural antibodies in approximately the same concentration as the corresponding sera. Under these conditions the synovial membrane has lost its function as a barrier to immune bodies.

TABLE II

EXAMINATION OF SYNOVIAL EFFUSIONS AND BLOOD-SERA FOR ANTI-A AND ANTI-B ISO-AGGLUTININS

\begin{tabular}{|c|c|c|c|c|c|c|c|}
\hline \multirow{3}{*}{$\begin{array}{l}\text { No. of } \\
\text { Cases }\end{array}$} & \multirow{3}{*}{$\begin{array}{c}\text { Record } \\
\text { No. }\end{array}$} & \multirow{3}{*}{$\begin{array}{l}\text { Blood } \\
\text { Group }\end{array}$} & \multirow{3}{*}{ Diagnosis } & \multicolumn{4}{|c|}{ Titre of Iso-Agglutinins } \\
\hline & & & & \multicolumn{2}{|c|}{ Anti-B } & \multicolumn{2}{|c|}{ Anti-A } \\
\hline & & & & Serum & $\begin{array}{l}\text { Synovial } \\
\text { Effusion }\end{array}$ & Serum & $\begin{array}{l}\text { Synovial } \\
\text { Effusion }\end{array}$ \\
\hline 7 & $\begin{array}{l}1 \\
2 \\
3 \\
4 \\
5 \\
6 \\
7\end{array}$ & $\begin{array}{l}\text { A } \\
\text { ", } \\
\text { " } \\
\text { ", }\end{array}$ & Osteo-Arthritis & $\begin{array}{r}256 \\
16 \\
32 \\
64 \\
256 \\
64 \\
16\end{array}$ & $\begin{array}{r}128 \\
32 \\
32 \\
64 \\
128 \\
64 \\
16\end{array}$ & & \\
\hline 6 & $\begin{array}{r}8 \\
9 \\
10 \\
11 \\
12 \\
13\end{array}$ & $\begin{array}{l}\text { ”, } \\
\text { ”, } \\
\text { ", }\end{array}$ & Rheumatoid Arthritis & $\begin{array}{r}32 \\
32 \\
32 \\
64 \\
64 \\
256\end{array}$ & $\begin{array}{r}32 \\
16 \\
32 \\
32 \\
16 \\
256\end{array}$ & & \\
\hline 2 & $\begin{array}{l}14 \\
15\end{array}$ & ", & Ankylosing Spondylitis & $\begin{array}{r}64 \\
256\end{array}$ & $\begin{array}{r}64 \\
128\end{array}$ & & \\
\hline 3 & $\begin{array}{l}16 \\
17 \\
18\end{array}$ & ”, & Infective Arthritis & $\begin{array}{r}128 \\
32 \\
128\end{array}$ & $\begin{array}{r}128 \\
32 \\
64\end{array}$ & & \\
\hline 1 & 19 & ", & Palindromic Rheumatism & 32 & & & \\
\hline 1 & 20 & B & Rheumatoid Arthritis & & & 128 & 128 \\
\hline 1 & 21 & ", & Still's Disease & & & 64 & 64 \\
\hline 4 & $\begin{array}{l}22 \\
23 \\
24 \\
25\end{array}$ & $\begin{array}{l}\text { O } \\
\text { " } \\
\text { " }\end{array}$ & Osteo-Arthritis & $\begin{array}{l}64 \\
16 \\
64 \\
16\end{array}$ & $\begin{array}{l}64 \\
16 \\
64 \\
16\end{array}$ & $\begin{array}{r}64 \\
32 \\
8 \\
32\end{array}$ & $\begin{array}{r}64 \\
16 \\
8 \\
32\end{array}$ \\
\hline 4 & $\begin{array}{l}26 \\
27 \\
28 \\
29\end{array}$ & $\begin{array}{l}\text { ", } \\
\text { ", }\end{array}$ & Rheumatoid Arthritis & $\begin{array}{l}32 \\
64 \\
16 \\
16\end{array}$ & $\begin{array}{l}64 \\
64 \\
16 \\
16\end{array}$ & $\begin{array}{r}128 \\
256 \\
16 \\
32\end{array}$ & $\begin{array}{r}128 \\
128 \\
16 \\
32\end{array}$ \\
\hline 1 & 30 & ", & Ankylosing Spondylitis & 32 & 32 & 128 & 128 \\
\hline 1 & 31 & , & Intermittent Hydrarthrosis & 16 & 8 & 32 & 16 \\
\hline 1 & 32 & ", & Infective Arthritis & 32 & 32 & 32 & 32 \\
\hline 1 & 33 & ", & Gout & 32 & 16 & 32 & 16 \\
\hline
\end{tabular}


Presence of Acquired Immune Antibodies

Material.-A volunteer, Mr. H., aged 79 years, suffering from osteo-arthritis of both knee joints accompanied by effusions, was given six injections of $0.5 \mathrm{ml}$. P.T.A.P. in separate intramuscular sites on the one occasion. After 27 days, and again, 72 days later, the antibody titre in his serum and in the synovial fluid of each knee joint was determined. The antitoxin titres were estimated by the method of Römer and Sames (1909), as developed by Glenny and Llewellyn-Jones (1931).

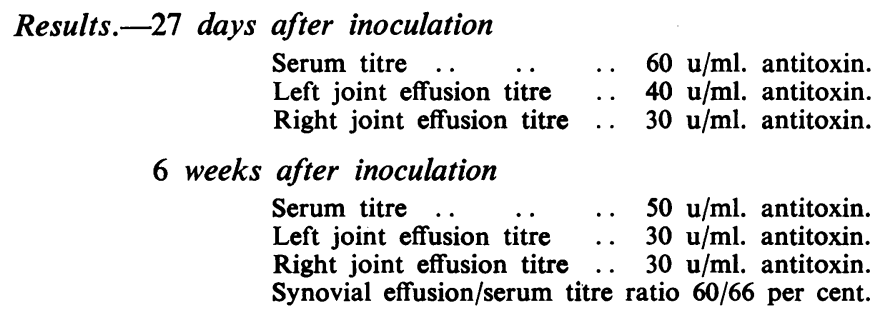

These results showed a marked difference in the behaviour of the synovial membrane in this patient as compared with the normal volunteer who was similarly investigated. Whereas in the normal volunteer the synovial fluid/serum ratio was under $7 \cdot 5$ per cent., in this patient it was $60 / 66$ per cent., i.e. about ten times as great. This would seem to indicate that even in a " non-infective " type of arthritis the synovial membrane allows acquired immune antibodies to pass much more readily.

\section{Investigation of Synovial Effusions from Arthritic Human Knee Joints for the Presence of Blood-group Specific Substances}

Materials.-Synovial fluid and sera were collected and examined as described above. Saliva was obtained on the day of the puncture of the knee joint. Equal amounts of normal saline and saliva were mixed and heated in a water-bath at $100^{\circ} \mathrm{C}$. for 3 minutes. This was done in order to destroy the enzymes present in the saliva. The samples were freed from any insoluble material by centrifuging. Grouping sera of persons of groups A and B were stored in $2 \mathrm{ml}$. tubes at $4^{\circ} \mathrm{C}$. without addition of preservative. A fresh ampoule of serum was used for each test.

Technique of Inhibition Test.- The method used was that of Aubert, Boorman, and Dodd (1942). Equal parts of the solution to be tested were mixed with the standard grouping of serum. The test solutions were:

(a) The patient's serum ( 1 in 2 normal saline).

(b) The patient's saliva ( 1 in 2 normal saline).

(c) The patient's synovial fluid (1 in 2 normal saline).

These mixtures were allowed to stand at $37^{\circ} \mathrm{C}$. for one hour. The mixtures were then titrated in saline using the standard technique described above. An anti-A grouping serum was used if the patient belonged to group A, and an anti-B grouping serum if the patient was of group B. The titrations were then compared, and the inhibitions of the grouping serum by the patients' synovial fluid were expressed at "inhibition index ". The inhibition index is the number of times the original titre was reduced, e.g. an inhibition index of 16 indicates that the titre had been reduced to $\frac{1}{16}$ of its original value.

Results.-Eighteen cases of arthritic disorders, all of them being " secretors", belonging to groups A and B were examined. The inhibition index was high or moderate in the saliva, low or twice absent in the sera, and mostly missing in the synovial effusions. 
TABLE III

BLOOD-GROUP SPECIFIC SUBSTANCES IN SYNOVIAL EFFUSIONS, SALIVA, AND SERUM OF "SECRETORS" OF GROUPS A AND B

\begin{tabular}{|c|c|c|c|c|c|c|}
\hline \multirow{2}{*}{$\begin{array}{l}\text { No. of } \\
\text { Cases }\end{array}$} & \multirow{2}{*}{$\begin{array}{c}\text { Record } \\
\text { No. }\end{array}$} & \multirow{2}{*}{$\begin{array}{l}\text { Blood } \\
\text { Group }\end{array}$} & \multirow{2}{*}{ Diagnosis } & \multicolumn{3}{|c|}{ Inhibition Index } \\
\hline & & & & $\begin{array}{l}\text { Synovial } \\
\text { effusion }\end{array}$ & Saliva & Serum \\
\hline 6 & $\begin{array}{l}1 \\
2 \\
3 \\
5 \\
6 \\
7\end{array}$ & $\begin{array}{l}\text { A } \\
\text { ”, } \\
\text { ”, } \\
\text { ", }\end{array}$ & Osteo-Arthritis & $\begin{array}{l}0 \\
0 \\
0 \\
0 \\
0 \\
2\end{array}$ & $\begin{array}{c}128 \\
\text { Not titrated } \\
128 \\
64 \\
32 \\
\text { Not titrated }\end{array}$ & $\begin{array}{l}2 \\
2 \\
4 \\
4 \\
8 \\
2\end{array}$ \\
\hline 4 & $\begin{array}{r}8 \\
9 \\
11 \\
12\end{array}$ & ", & Rheumatoid Arthritis & $\begin{array}{l}2 \\
2 \\
0 \\
0\end{array}$ & $\begin{array}{c}64 \\
64 \\
\text { Not titrated } \\
32\end{array}$ & $\begin{array}{c}4 \\
4 \\
\text { Not titrated } \\
8\end{array}$ \\
\hline 2 & $\begin{array}{l}14 \\
15\end{array}$ & ", & Ankylosing Spondylitis & $\begin{array}{l}\mathbf{0} \\
\mathbf{0}\end{array}$ & $\begin{array}{l}\text { Not titrated } \\
64\end{array}$ & $\begin{array}{l}0 \\
4\end{array}$ \\
\hline 3 & $\begin{array}{l}16 \\
17 \\
18\end{array}$ & ", & Infective Arthritis & $\begin{array}{l}0 \\
2 \\
0\end{array}$ & $\begin{array}{c}64 \\
128 \\
\text { Not titrated }\end{array}$ & $\begin{array}{l}2 \\
4 \\
4\end{array}$ \\
\hline 1 & 19 & , & Palindromic Rheumatism & $\mathbf{0}$ & Not titrated & 0 \\
\hline 1 & 20 & B & Rheumatoid Arthritis & 0 & 64 & 8 \\
\hline 1 & 21 & ", & Still's Disease & 2 & 128 & 8 \\
\hline
\end{tabular}

The absence of group specific substances might have been due to their destruction by enzymes present in the synovial fluid, because it was not possible to heat synovial fluid to $100^{\circ} \mathrm{C}$. (as we did the saliva) to destroy the enzymes. Unheated synovial fluid was therefore added to heated saliva, and the inhibition test was carried out with these mixtures after 24 hours. The absence of such hypothetical enzymes was confirmed by the fact that addition of unheated synovial fluid to heated saliva did not interfere with the inhibition.

\section{Discussion}

The general properties of the natural anti-A and anti-B agglutinins are similar to those of immune bodies. Both natural and acquired immune antibodies are present in the globulin fraction of the plasma, and, in moderate amounts, in the tissue fluids, which are rich in protein. No reference was found in the literature to their occurrence in synovial fluids and synovial effusions. Our results show that natural and acquired immune antibodies are missing, or present in traces only, in the synovial fluid of the normal human knee joint. It is concluded that the undamaged synovial membrane of this joint provides a barrier to the passage of these substances.

The synovial membrane has no endothelial lining like the peritoneum, and the function of the barrier is probably confined to the wall of the extensive capillary 
and lymph bed. This is in agreement with the view of Davies (1949) that only substances of low molecular weight pass easily in both directions across such capillary membranes.

The findings obtained on material from normal joints are in sharp contradistinction to those obtained on material from diseased joints. (Unfortunately acute traumatic effusions could not be investigated as the material obtained was haemorrhagic.) We did not expect to find in all our synovial fluids from abnormal joints an antibody titre which was as high or nearly as high as that in the corresponding serum. These results indicate that in the diseased joint a free passage of antibodies may take place from the capillary and lymph bed of the synovial membrane into the synovial cavity.

The study of group specific substances is interesting, although in regard to the permeability of the synovial membrane to soluble group substances from the plasma into the joint cavity the results do not allow any conclusion. The method was not sensitive enough to detect in the viscous synovial fluid quantities as low as those detected in the serum. On the other hand, the presence of large quantities of soluble group substances in the saliva, and their nearly complete absence in the synovial effusions, points to a distinct difference in the mucins of saliva and synovial effusions. Mucins are a complex of proteins united to polysaccharides which possess acidic properties, and by virtue of the acid group, two types of mucin can be distinguished: those with the sulphuric acid groups, and those with the uronic acid units. The former are mostly mucins of epithelial origin and stain metachromatically. The latter are representatives of the mesenchymal mucins, have been found in the vitreous humour, umbilical cord, and synovial fluid, and are termed collectively hyaluronic acid mucins or hyaluronates. Our results show that the blood-group substance which is secreted in epithelial and endothelial mucinous fluids, is absent from the mucinous fluids of mesenchymal origin. It thus seems possible to distinguish serologically between the mucins of mesenchymal secretion and those which originate from cells of ectodermal or endodermal derivation.

\section{Summary}

(1) The normal human synovial membrane did not allow the passage of natural or acquired immune antibodies.

(2) These antibodies were present in synovial fluid obtained from diseased joints.

(3) The blood-group specific substances which are normally present in mucinous secretions of ectodermal and endodermal derivation were not found in the mesenchymal synovial fluid.

We wish to thank the Empire Rheumatism Council and Dr. W. S. C. Copeman for their interest in this work and the help and facilities they have afforded us, and Professor C. Rimington for his valuable help and stimulating suggestions.

This work was carried out when Dr. T. C. Highton was holding a Nuffield Fellowship in chronic rheumatic diseases, and Dr. K. Maunsell was receiving a grant from the Empire Rheumatism Council. 
REFERENCES

Aubert, E. F., Boorman, K. E., and Dodd, B. E. (1942). J. Path. Bact., 54, 89.

Davies, D. V. (1949). Brit. med. Ass. Proc. ann. Mtg, p. 206.

Glenny, A. T., and Llewellyn-Jones, M. (1931). J. Path. Bact., 34, 143.

Römer, P. H., and Sames, T. (1909). Z. Immun. Forsch., 3, 344.

Taylor, G. L., and Ikin, E. W. (1939). Brit. med. J., 1, 1027.

La Membrane Synoviale:

Quelques Observations sur les Articulations Humaines Normales et Arthritiques

RÉSUMÉ

(1) La membrane synoviale humaine normale ne laissait pas passer les anticorps immunisants naturels ou acquis.

(2) Ces anticorps étaient présents dans le liquide synovial provenant des articulations malades.

(3) Les substances spécifiques des groupes sanguins, normalement présentes dans les sécrétions d'origine ectodermique ou endodermique, ne furent pas trouvées dans le liquide synovial mésenchymateux.

\section{La Membrana Sinovial:}

Algunes Observaciones Sobre las Articulaciones Humanas Normales y Artriticas

RESUMEN

(1) La membrana sinovial humana normal no deja pasar los anticuerpos imunisantes naturales 0 adquiridos.

(2) Estos anticuerpos estaban presentes en el líquido sinovial procedente de articulaciones enfermas.

(3) Las substancias específicas de los grupos sanguineos, normalemente presentes en las secreciones de origen ectodérmico o endodérmico, no fueron encontradas en el líquido sinovial mesenquimatoso. 